\title{
Classification Model of Urban Riverside Landscape Using the Oder River as an Example
}

\author{
Iwona D. Orzechowska-Szajda* \\ Institute of Landscape Architecture, Wrocław University of Environmental and Life Sciences, Wrocław, Poland
}

Received: 25 October 2018

Accepted: 13 January 2019

\begin{abstract}
This study aims to present the classification model of urban riverside landscapes. The subject of the research is the riverside landscape of Wroclaw, Poland, as seen from the level of the Oder River. The assessment was made with the use of the statistical method - the analysis of discriminant functions. The assessment was conducted on the basis of a detailed analysis of the linear film picture. In order to build the model on the passage of $70 \mathrm{~km}$, eight parameters, in 354 points every $200 \mathrm{~m}$, were assessed. The statistical method was used for modeling. The developed model, based on the 8 parameters, allows for classifying landscapes into the 5 classes of landscape value on the grounds of the classification values for cases. The efficiency of the developed model is estimated to be on the level of $77 \%$. The built model can constitute an objective tool of landscape classification that supports making planning decisions. The application of the model in spatial planning would be allowed to include aesthetic and landscape aspects in the process of developing riverside areas of a city.
\end{abstract}

Keywords: the classification of landscape; urban riverside landscape; the analysis of discriminant functions, parameters of landscape

\section{Introduction}

The issues concerning revitalization and reconstruction of riversides and the development of city spaces, according to the idea of a well-balanced development and the renewed idea of turning city development toward the direction of a river, have become a priority in the actions of the authorities of riverside cities in recent years. These actions aim at providing the comprehensive and multifunctional development of

*e-mail: iwona.orzechowska-szajda@upwr.edu.pl a city, going hand in hand with environment protection and preserving cultural values. The landscape virtues of city areas, situated by a river, in the face of historical, economic and cultural transformations, have gained new value in the last decade as they emphasize the individuality and uniqueness of riverside cities and they are becoming very important areas for the urban development of cities. The junction of the city areas and the natural habitat represented by a river and the different types of landscapes alongside the open space of a river all contribute to the fact that these landscapes are extremely valuable and sensitive to the introduced changes. Daniel and Meitner [1], Filova et al. [2], Meyer and Grabaum [3], Ruelle et al. [4], Zhao et al. [5] and Zhu et al. [6] indicate that landscape quality assessment 
is an important component of environmental planning and management. Therefore, in order to conduct a thorough analysis of a present state, preceding the indication of the directions of city riverside landscape management, it is necessary to include (apart from generally known measurements and indicators used in spatial planning) landscape values as well.

The issues concerning the evaluation of landscape, types and divisions of methods, and methodological problems are the main subjects of numerous research works within the domain of different spheres of science. These publications, mainly from the onset of research development concerning landscape assessment, have laid the ground for further academic studies that are dominated by mainstream research on open, natural and extra-urban landscapes [7-15]. Unfortunately, there is comparatively little research on urban landscape management $[5,16]$.

In the academic research on landscape evaluation, social preference tests are mostly used [6, 7, 10, 16-24], whereas in practice in landscape management experts' evaluation is widely adopted [25]. Churchward et al. [26] conducted an in-depth assessment of the methods used mainly in the U.S. in management to assess the visual impact on the landscape. Indicators applied in various landscape evaluation models have been discussed in the study of Cassatella and Peano [27], and an overview of studies on influencing factors was given by Kearney and Bradley [28]. And numerous research conducted over the last decades has shown that the quality of landscape mark is influenced by landscape elements, features and also features of tested respondents. Although a lot of research touches upon the issue of the influence that respondent's features have on preferences [7, 10, 21, 23, 25, 29-30], then Strumse's [31] results proved that the differences between evaluating groups were relatively small in comparison to the influence of landscape elements and features.

There are few studies that explain the methodological approach to the models. There is a research trend based on ecological models. Gómez-Sal et al. [32] have prepared a conceptual model which takes into account five dimensions that are considered independent: ecological, productive, economic, social and cultural evaluative systems. Although this method was used to evaluate rural and natural landscapes, the authors only presented the social and economic aspects without taking into consideration the visual one. Moreover, this model is of a descriptive character.

Similarly, the MULBO model [3], which is based on abiotic, biotic and socio-economic factors, omits the aesthetic landscape function. Zhao and co-workers [5]

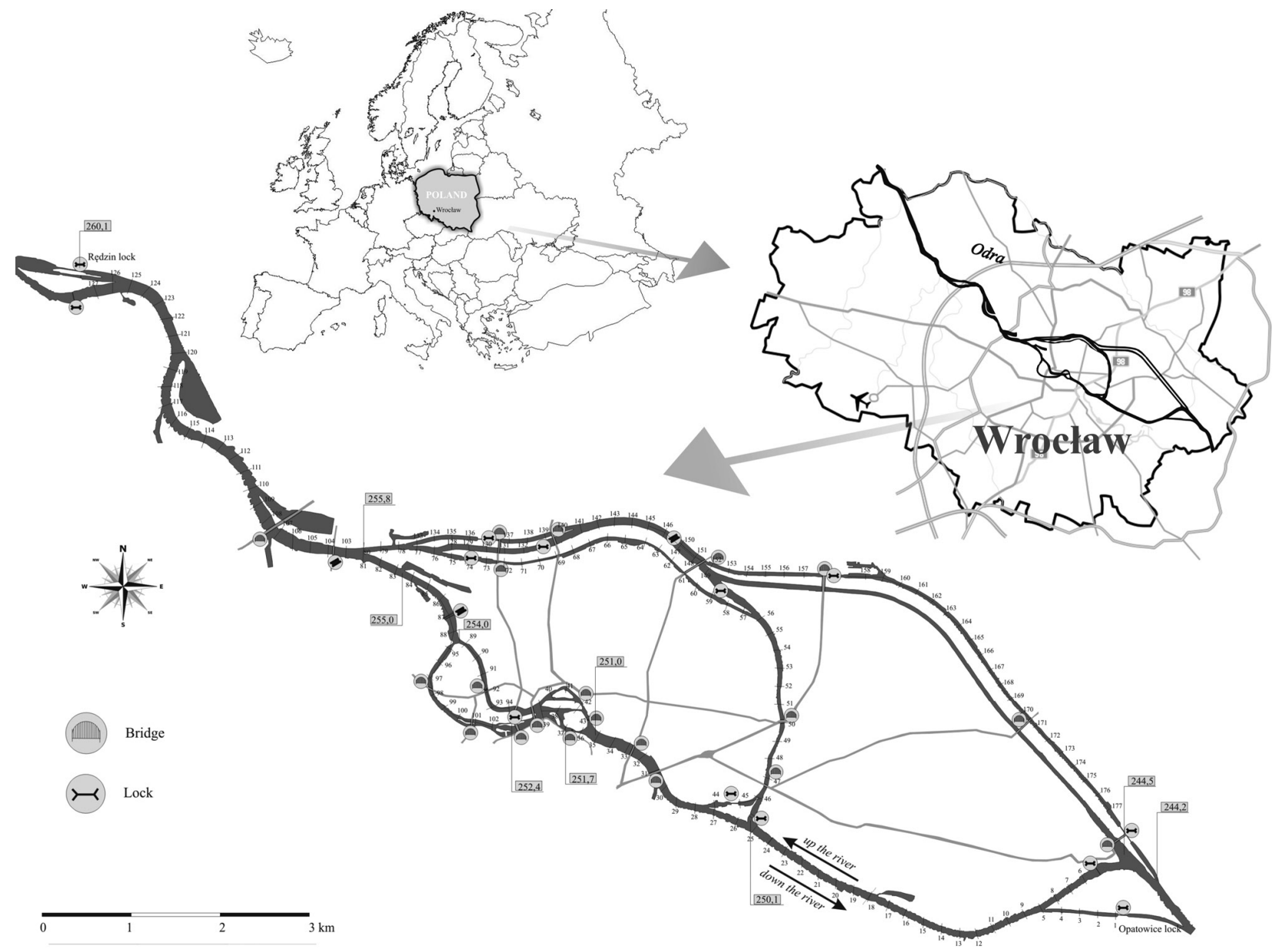

Fig.1. The research area (author study). 
evaluated a model based on 11 parameters (plain form of river, plants on water, river accessibility, plants on river side, types of riparian vegetation, coverage of riparian vegetation, coverage of riparian vegetation, buildings, number of colors, degree of wilderness, perspective) in order to manage riverside areas, dividing them into urban and rural rivers.

Attentiveness to the aesthetic quality of a landscape is considered a public duty [25]. Recently, the planning process has become a very complex and complicated issue in technical, physical, social, and economic aspects. Decisions made in landscape management, especially in the so sensitive environment as the riverside areas, should always strive for compromise [32]. When making decisions, having knowledge of what resources we are dealing with is crucial [6]. Although many researchers have emphasized the significance of aesthetic aspects in landscape management, aesthetic aspects are often ignored due to the failure to apply quantitative indicators for visual quality [19]. This is why this article aims at presenting a model for riverside landscape classification in which quantitative measures have been applied in order to determine the physical features of a landscape on the basis of recorded video images.

\section{Materials and Methods}

The subject of this research is the riverside landscape of Wroclaw as seen from the level of the Oder River. The assessment was made on the basis of the analysis of the linear picture registered by means of a professional Sony camcorder in May 2012 between 8 a.m. and 6 p.m. in steady lighting conditions. The camcorder was placed in the front part of a motor boat in such a way that the angle of view in relation to the river level was always constant.
The borders of the research area are limited by Opatowice Lock (kilometer 243,5 of the Oder), Bartoszowice (kilometer 244,2 of the Oder) and Rędzin Lock ( $\mathrm{km} \mathrm{260,1} \mathrm{of} \mathrm{the} \mathrm{Oder).} \mathrm{In} \mathrm{order} \mathrm{to} \mathrm{build} \mathrm{the}$ valorization model of the Oder riverside landscape of Wroclaw, the particular parameters in the points situated every $200 \mathrm{~m}$ were assessed. Altogether, $70 \mathrm{~km}$ of the Oder landscape within the administrative borders of the city (354 valorization areas) were pointed out, including 177 up and down the river (Fig. 1).

In each of 354 points, three groups of parameters were analyzed:

- Parameters concerning the river (Table 1): the width of the river bed (width of the river equals the distance between river banks, as marsh land [3], flora.

- Parameters concerning the city (Table 2): landscape dominants, destructive elements, historical value.

- Parameters concerning perception (Table 3): colour and the two author's parameters, including horizontal complexity coefficient and vertical complexity coefficient.

The landscape, based on observation, was classified into five landscape value classes:

- VL - very low value of landscape: views very restricted to only the view between river banks, no attention-drawing elements, monotonous landscape.

- L - low value of landscape: views allowing for a view into the background, no attention-drawing elements, not very interesting landscape.

- M - medium value of landscape: wider views, monotonous landscape, single attention-drawing elements.

- H - high value of landscape: distant wide views, positive attention-drawing elements, changeable landscape.

- VH - very high value of landscape: distant wide views, many attention-drawing elements, changeable landscape, dynamic, unique landscape.

Table 1. Number grading of the parameters concerning the river

\begin{tabular}{|c|c|c|c|c|c|c|}
\hline \multicolumn{7}{|c|}{ Parameters concerning the river } \\
\hline \multicolumn{7}{|c|}{ WIDTH OF THE RIVER BED [RB] } \\
\hline \multirow[t]{2}{*}{1.} & $\begin{array}{l}\text { Description } \\
\text { of factor }\end{array}$ & Narrow $0-5 \mathrm{~m}$ & $\begin{array}{c}\text { Medium } \\
5-20 \mathrm{~m}\end{array}$ & $\begin{array}{l}\text { Wide } \\
20-100 \mathrm{~m}\end{array}$ & $\begin{array}{l}\text { Very } \\
>1\end{array}$ & de \\
\hline & $\begin{array}{l}\text { Number } \\
\text { grade }\end{array}$ & 1 & 2 & 3 & & \\
\hline \multirow{8}{*}{2.} & \multicolumn{6}{|c|}{ FLORA $[\mathrm{F}]$} \\
\hline & \multirow{3}{*}{\multicolumn{3}{|c|}{ Description of factor }} & \multicolumn{3}{|c|}{ Number of species } \\
\hline & & & & 0 & $1-3$ & $\geq 4$ \\
\hline & & & & \multicolumn{3}{|c|}{ Number grade } \\
\hline & \multirow{4}{*}{ Structure } & Lack of flora & \multirow{4}{*}{$\begin{array}{l}\text { Number } \\
\text { grade }\end{array}$} & 0 & - & - \\
\hline & & $\begin{array}{c}\text { Flora covers the stripe of the width from } 0-12 \mathrm{~m} \text { (single specimens } \\
\text { or small groups) }\end{array}$ & & - & 1 & 2 \\
\hline & & Flora covers the stripe of the width from $12-20 \mathrm{~m}$ & & - & 2 & 3 \\
\hline & & Flora covers the stripe of the width over $20 \mathrm{~m}$ (compact structure) & & - & 4 & 5 \\
\hline
\end{tabular}


Table 2. Number grading of the parameters concerning the city.

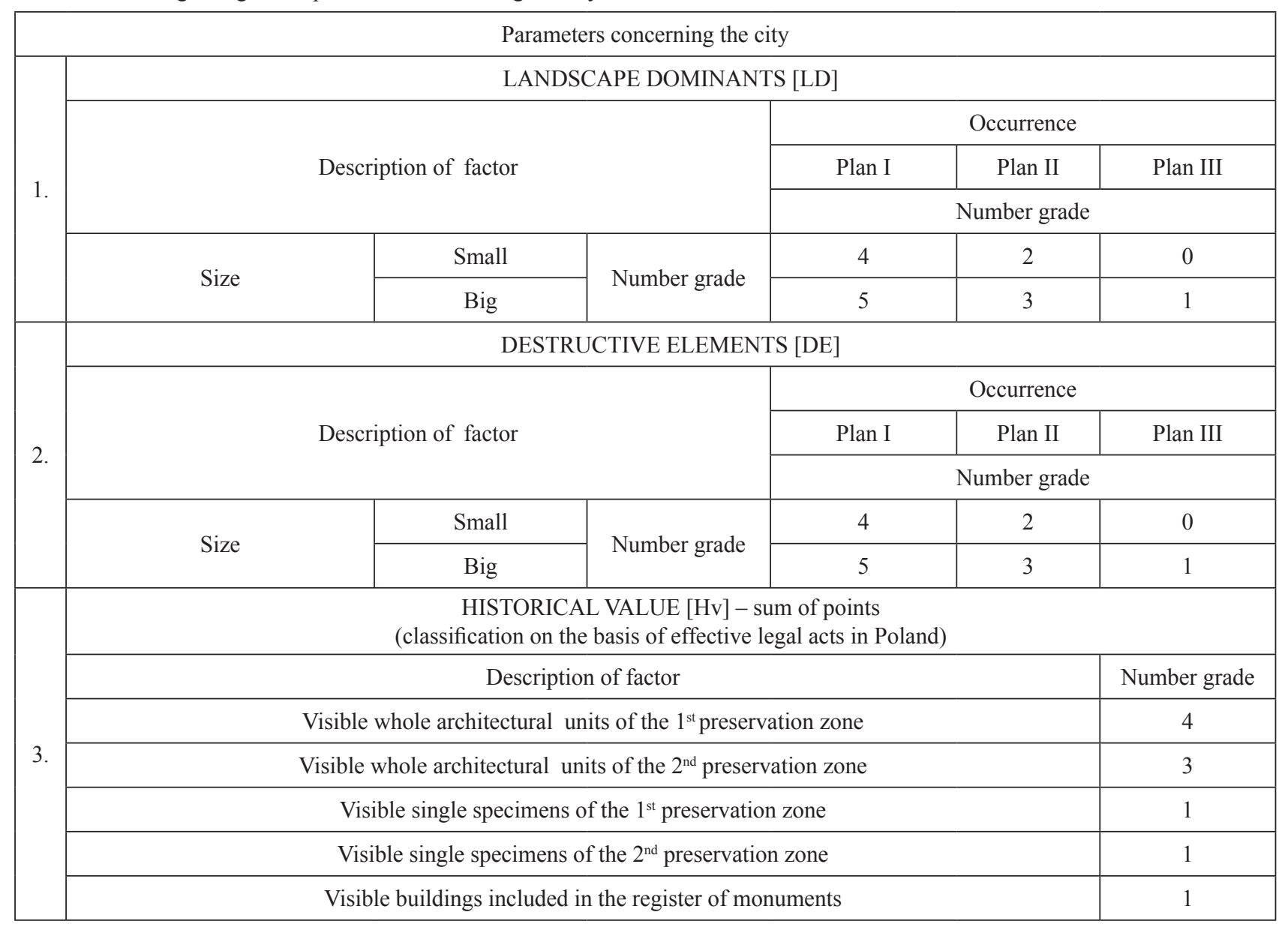

From the database for 354 cases, 2/3 of those chosen at random were used to build the model, while the remaining part of data was used to check the quality of prediction of the created model.

The static method was used to build the model - the analysis of discriminant functions of the program STATISTICA. The analysis of discriminant function is used to determine questions relating to the classification of phenomena into certain groups. From the arithmetic point of view, the main underlying idea of the discriminant function analysis is determining if groups differ in view of the means of a certain variable and next in view of the use of this variable to predict affinity to a certain group. The most common use of the analysis of discriminant function involves the application of numerous measurements (coefficients) to the research in order to isolate those that discriminate groups. Palmer and Zube [33] also used the analysis of discriminant function to predict landscape classification on the basis of social preference. The analysis of a discriminant function is used to decide which variables distinguish (discriminate) two or more naturally forming groups, for it searches for rules of conduct that aim at subjugating multidimensional sites to one of many populations of known parameters by adhering to the fewest possible classification errors. This was successfully used in wide research in many areas, especially in biologicalmedical sciences, to develop classifications based upon physical and chemical characteristics. Palmer and Zube [33] described the process of analysis of discriminant function in detail.

The characteristic feature of the applied method is the fact that it is conducted in stages. In the first stage, the stepwise analysis of discriminant functions was carried out. The stepwise procedure is controlled by appropriate values of $\mathrm{F}$ to enter and $\mathrm{F}$ to remove. The value of $\mathrm{F}$ for a variable indicates its statistical significance in discriminating between certain groups. The discriminant model was built in eight steps.

Furthermore, the canonical analysis was implemented, which resulted in determining functions that discriminate between certain groups by means of optimal combination of variables. As far as arithmetic is concerned, the analysis of canonical correlation is conducted on the basis of which successive functions and canonical roots are calculated (the notion root applies to eigenvalues linked with appropriate discriminant functions). These functions are independent or orthogonal, which means that their use in discriminating between groups does not coincide. 
Table 3. Number grading and the method of determining the parameters concerning perception.

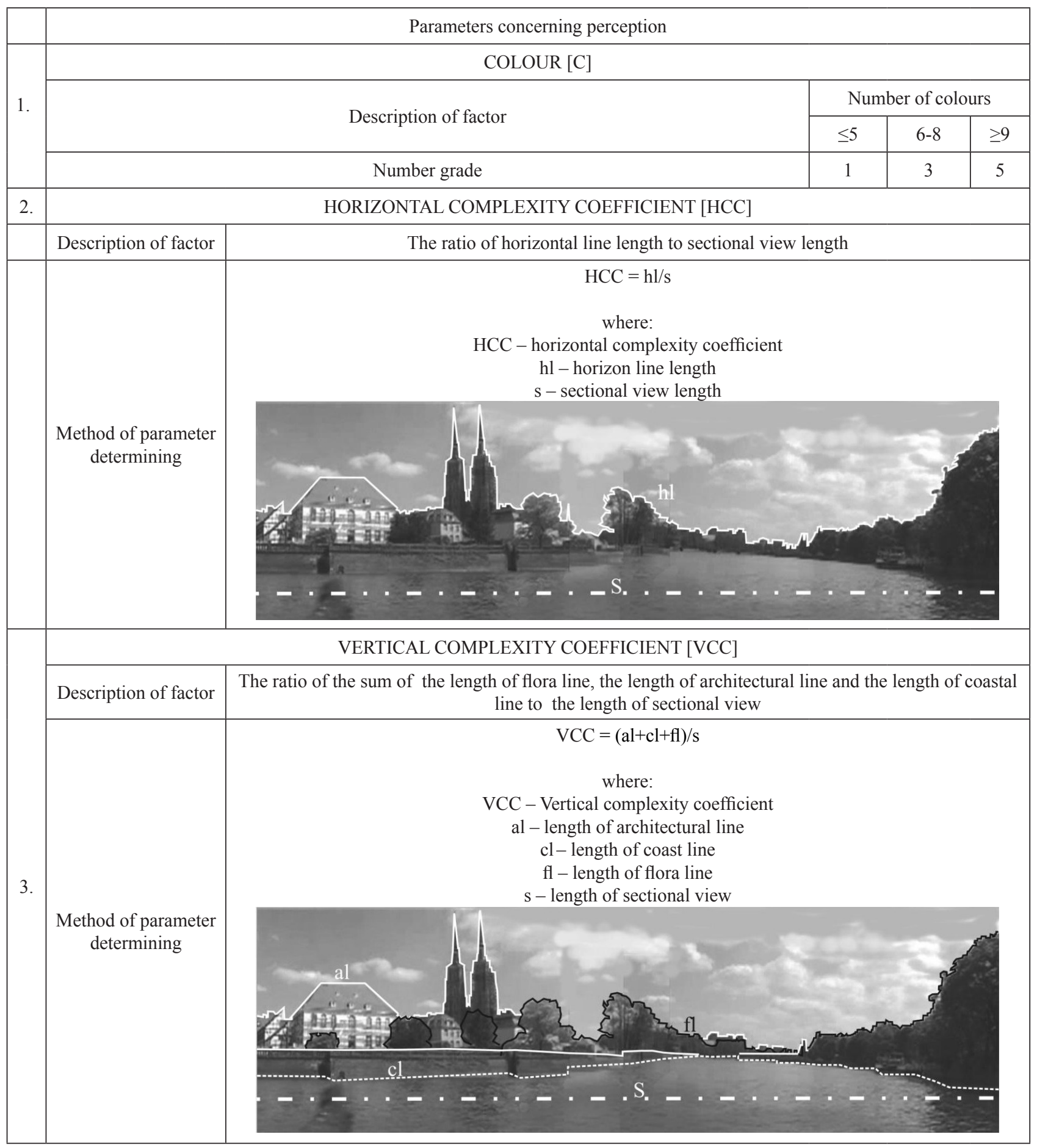

In the final stage, on the basis of the best discriminant function, the classification model of the riverside landscape of Wrocław was built. This model comprised 5 classification functions. Each function allows us to calculate the classification values for each case in each group by means of the following formula:

$S i=c i+w i 1 \times x 1+w i 2 \times x 2+\cdots+w i m \times x m$ ...where:

- index i defines a certain group,

- indexes $1,2, \ldots, \mathrm{m}$ define $\mathrm{m}$ of variables,

- $c_{i}$ is a constant for $i$ of this group,

- $\mathrm{w}_{\mathrm{ij}}$ is a weight for $\mathrm{j}$ of this variable while calculating the classification value for $i$ of this group,

- $x_{j}$ is an observed value for a certain case for $j$ of this variable,

- $\mathrm{S}_{\mathrm{i}}$ signifies the resultant classification score. 


\section{Results and Discussion}

The standard statistics used in the stepwise analysis of discriminant functions to determine the statistical significance of the discriminative power of the built model are as follows: the level of significance $p$ and the level of implementation $\mathrm{F}$ - the level of statistical value of $F$ decides on the order of introducing a variable into the model. The value of Wilks' lambda is enclosed in brackets from 1,0 (lack of discriminative power) to 0,0 (perfect discriminative power), whereas the partial value of Wilks' lambda is a Wilks' lambda defining the specific contribution of a certain variable into the process of group discrimination.

Subsequently, the parameters of the highest values of $\mathrm{F}$ to enter were introduced (Table 4). The factor of historical value was introduced to the model as the first one, and the horizontal complexity coefficient was introduced to the model as the last one, which was done in the eighth step of the stepwise analysis of the discriminant function.

As a result of the conducted canonical analysis, 4 discriminant functions were obtained (the results of the canonical analysis are presented in Tables 5 and 6). While comparing the calculated discriminant functions, it can be noticed that the best level of $p$ was achieved by functions 1 and 2, whereas the lowest values of the Wilks' lambda were recorded for function 1. The analysis of the means of the canonical variables shows as well that function 1 discriminates between certain groups best (Table 6). Function 1 (Root 1) clearly discriminates between classes VH, $\mathrm{H}$ and VL. The approximated values of the means of canonical variables were obtained for class $\mathrm{L}$ and $\mathrm{M}$. Function 2 clearly discriminates between classes VL and M, while function 3 discriminates between class VL and function 4 discriminates between class L.

The model was built on the basis of the first discriminant function (the classification functions) and includes 5 formulas:

$$
\begin{gathered}
0,8392 \times H v+12,8670 \times R B-0,1717 \times L D+1,2957 \\
\times F+1,5694 \times D E+10,0521 \times V C C+2,4827 \times C \\
-2,4635 \times H C C-36,6202=\boldsymbol{V L}
\end{gathered}
$$$$
-0,8403 \times H v+14,9771 \times R B+0,3887 \times L D+
$$$$
1,6550 \times F-0,1802 \times D E+11,8779 \times V C C+1,9210
$$$$
\times C-2,6846 \times H C C-41,1003=\boldsymbol{L}
$$$$
-0,8897 \times H v+17,3897 \times R B+0,4635 \times L D+
$$$$
2,3918 \times F-0,0129 \times D E+11,6220 \times V C C+2,5640
$$$$
\times C-2,2115 \times H C C-50,4446=\boldsymbol{M}
$$

$3,055 \times H v+19,409 \times R B+1,815 \times L D+3,408 \times F$

\begin{tabular}{|c|c|c|c|c|c|c|c|c|c|}
\hline \multirow{3}{*}{$\begin{array}{l}\overline{0} \\
0 \\
0 \\
\Xi \\
0 \\
\frac{\Xi}{ \pm} \\
0 \\
\frac{0}{0} \\
0 \\
0 \\
0\end{array}$} & $\begin{array}{l}\dot{\overline{0}} \\
\stackrel{0}{0} \\
\stackrel{0}{0} \\
1\end{array}$ & \begin{tabular}{l}
\multirow{2}{0}{} \\
2 \\
ले \\
ते
\end{tabular} & $\begin{array}{l}\frac{2}{5} \\
\text { in } \\
\text { I }\end{array}$ & 竎 & సু & $\begin{array}{l}\infty \\
\infty \\
\sim \\
\sim \\
n \\
n\end{array}$ & $\frac{\hat{\sigma}}{\frac{\sigma}{2}}$ & 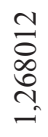 & ' \\
\hline & 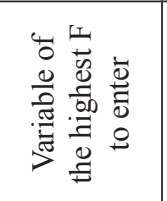 & $\stackrel{q}{a}$ & 9 & I & 岶 & $\underbrace{U}_{>}$ & $U$ & Uِ & 1 \\
\hline & 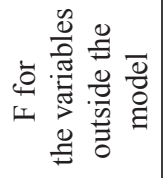 & 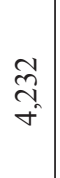 & $\begin{array}{l}\vec{\lambda} \\
\stackrel{+}{2}\end{array}$ & \begin{tabular}{l}
$\stackrel{\overbrace{}}{N}$ \\
ஸे \\
\multirow{+}{*}{}
\end{tabular} & $\begin{array}{l}\stackrel{\text { సे }}{\text { సे }} \\
\text { }\end{array}$ & $\begin{array}{l}\stackrel{\infty}{N} \\
\underset{\sim}{\sim}\end{array}$ & \begin{tabular}{l}
$\hat{ָ}$ \\
\multirow{+}{*}{}
\end{tabular} & 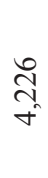 & , \\
\hline \multirow{8}{*}{$\begin{array}{l}\overline{0} \\
\overline{0} \\
\Xi \\
0 \\
\Xi \\
\Xi\end{array}$} & 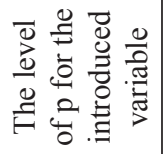 & 8 & $\begin{array}{l}8 \\
8 \\
8 \\
8 \\
8 \\
0\end{array}$ & $\begin{array}{l}8 \\
8 \\
8 \\
8 \\
0 \\
0\end{array}$ & $\begin{array}{l}8 \\
8 \\
8 \\
8 \\
8 \\
0\end{array}$ & $\begin{array}{l}\text { ㅇ. } \\
8 \\
8 \\
8 \\
8 \\
0\end{array}$ & $\begin{array}{l}\infty \\
\infty \\
\infty \\
\delta \\
\delta \\
0\end{array}$ & 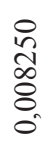 & $\begin{array}{l}\frac{m}{7} \\
\text { m } \\
\text { N } \\
0\end{array}$ \\
\hline & 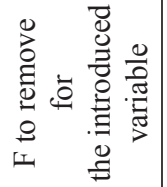 & 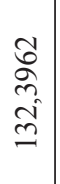 & $\begin{array}{l}\text { ర్ } \\
\text { సे } \\
\text { हे }\end{array}$ & \begin{tabular}{l}
$\frac{n}{7}$ \\
$\tilde{n}$ \\
\multirow{2}{0}{}
\end{tabular} & \begin{tabular}{l}
$n$ \\
\multirow{2}{*}{} \\
$\frac{1}{a}$
\end{tabular} & $\begin{array}{l}\stackrel{2}{a} \\
\stackrel{+}{\sigma} \\
\infty\end{array}$ & $\begin{array}{l}\infty \\
\infty \\
\sim \\
m \\
n\end{array}$ & $\frac{\infty}{\dot{ \pm}}$ & $\begin{array}{l}\text { D } \\
\infty \\
0 \\
\text { ஸ̂ }\end{array}$ \\
\hline & 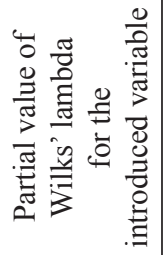 & 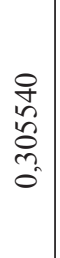 & 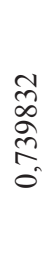 & 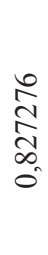 & $\begin{array}{l} \pm \\
8 \\
0 \\
n \\
\infty \\
0\end{array}$ & $\begin{array}{l}\vec{J} \\
\infty \\
\infty \\
\infty \\
0\end{array}$ & $\frac{n}{\frac{n}{\nabla}}$ & 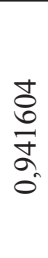 & 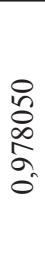 \\
\hline & 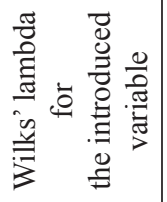 & $\begin{array}{l}8 \\
8 \\
8 \\
8 \\
-1\end{array}$ & \begin{tabular}{l}
0 \\
\multirow{1}{n}{} \\
$i n$ \\
0 \\
0 \\
0
\end{tabular} & 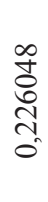 & $\begin{array}{l}\frac{1}{8} \\
\frac{1}{\infty} \\
\frac{1}{0}\end{array}$ & 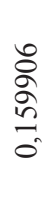 & $\begin{array}{l}\frac{1}{2} \\
\infty \\
\frac{1}{0}\end{array}$ & 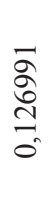 & \begin{tabular}{l}
0 \\
\multirow{2}{n}{} \\
$=$ \\
0
\end{tabular} \\
\hline & 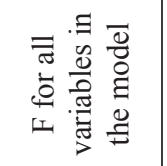 & 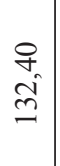 & $\begin{array}{l}\text { ईे } \\
\text { ळू } \\
\text { ภิ }\end{array}$ & 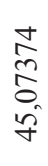 & 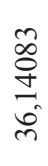 & 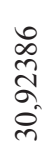 & 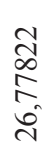 & $\begin{array}{l}\stackrel{a}{\vec{z}} \\
\stackrel{a}{\sigma_{n}} \\
\stackrel{v}{v}\end{array}$ & $\begin{array}{l}\exists \\
\equiv \\
0 \\
0 \\
0\end{array}$ \\
\hline & 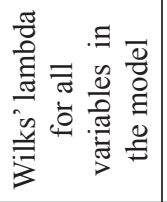 & $\begin{array}{l}\infty \\
2 \\
\tilde{n} \\
\hat{2} \\
n \\
0 \\
0\end{array}$ & 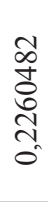 & $\begin{array}{l}\underset{8}{8} \\
\frac{\infty}{0} \\
0\end{array}$ & $\begin{array}{l}\overline{6} \\
\circ \\
\circ \\
\\
0\end{array}$ & $\begin{array}{l}\bar{\nabla} \\
\hat{\infty} \\
\frac{1}{0} \\
0\end{array}$ & $\begin{array}{l}\frac{n}{a} \\
\text { ò } \\
\text { a } \\
0\end{array}$ & $\begin{array}{l}n \\
n \\
n \\
\vdots \\
0\end{array}$ & $\begin{array}{l}\frac{0}{n} \\
\hat{\sigma} \\
= \\
0\end{array}$ \\
\hline & 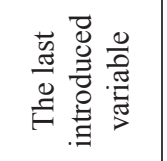 & 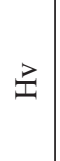 & $\underline{q}$ & 9 & 工 & 夏 & $\stackrel{U}{>}$ & $U$ & טִ \\
\hline & 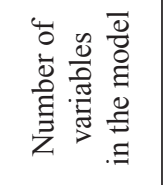 & - & $N$ & m & $\nabla$ & $n$ & 6 & $r$ & $\infty$ \\
\hline & $\frac{q}{i n}$ & - & 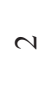 & $m$ & $\nabla$ & $n$ & 6 & $r$ & $\infty$ \\
\hline
\end{tabular}

$$
-0,485 \times D E+16,022 \times V C C+3,772 \times C
$$

$$
-4,764 \times H C C-102,050=\boldsymbol{V H}
$$


Table 5. The Chi-squared tests of the following roots (of the discriminant functions).

\begin{tabular}{|c|c|c|c|c|c|c|}
\hline & Eigenvalue & Canonical - R & Wilks' lambda & Chi-square & df & Level of $\mathrm{p}$ \\
\hline 1 & 3,596485 & 0,884558 & 0,116951 & 494,6531 & 32 & 0,000000 \\
\hline 2 & 0,540522 & 0,592342 & 0,537564 & 143,0733 & 21 & 0,000000 \\
\hline 3 & 0,181334 & 0,391790 & 0,828128 & 43,4693 & 12 & 0,000019 \\
\hline 4 & 0,022186 & 0,147323 & 0,978296 & 5,0579 & 5 & 0,408854 \\
\hline
\end{tabular}

...where:

$\mathrm{Hv}$ - historical value

$\mathrm{RB}$ - width of the river bed

LD - landscape dominants

$\mathrm{F}$ - flora

$\mathrm{DE}$ - destructive elements

VCC - vertical complexity coefficient

$\mathrm{C}$ - colour

HCC - horizontal complexity coefficient

$\mathrm{VL}$ - class - very low value of landscape

$\mathrm{L}$ - class - low value of landscape

$\mathrm{M}$ - class - medium value of landscape

$\mathrm{H}$ - class - high value of landscape

$\mathrm{VH}$ - class - very high value of landscape

The classification functions were obtained for each of the groups used directly to classify cases. A certain case is classified to the group for which it has the highest classification value.

The results of the model prediction by means of Mahalanobis distance are presented in Table 7 . This distance is a measure that can be used in the multidimensional space defined by the variables in the model; it is calculated between each case and the centre of each group (that is the centroid of a group, defined by appropriate group means for each variable). The closer the case to a certain group centroid, the more we can be assured that it belongs to this group. The cases that were classified by the model were marked in colour; the cases that were wrongly classified were marked with a thick box.

The summary of the developed model's prediction are presented in Table 8 . The highest number of correctly classified cases $(88,88 \%)$ belongs to class M. The high correctness of prediction (over 83\%) was also recorded for class VL. The lowest correctness of classification was obtained for class H $(61,9 \%$ correctly classified cases). The average correctness of the model classification amounts to $77,31 \%$.

The summary of the verification results of the model prediction quality for 116 cases are presented in Table 9. 100\% effectiveness was recorded for classes $\mathrm{H}$ and VL. The average quality of the verified model prediction equals $72,41 \%$. In the verified cases, no case classification to class VH was recorded.

Most of the methods used in the process of landscape management views the value of landscape as the sum of chosen factors, which can lead to the simplification of the complex phenomenon, which is called the landscape classification. The method of discriminant function analysis, used in this research, allows one to find and define the model of dependence of the examined parameters in relation to the potential classes.

Although this prepared model has the character of an expert approach, the model's methodical assumptions refer, as suggested by Kalivoda at al. [25], to scientifically proven findings regarding landscape perception. More recent work emphasizes the need for an integrated assessment of both expert and social assessment of landscape values and preferences [34]. As objective evaluation of the aesthetic value of different landscape elements is difficult, as stressed by Frank at al. [35], Dramstad at al. [19] or Tveit, Ode and Fry [36]. Results of worldwide research identifying indicators that influence the landscape valuation were used for the model's methodological principles.

The conducted research shows that the biggest positive influence on the distinction between certain classes of landscape value have the following factors, as follows: historic value, landscape dominants, and the vertical complexity coefficient. Destructive elements in the landscape have a negative impact. The analogous results can be traced in the work of Arriaza

Table 6. The means of canonical variables.

\begin{tabular}{|c|c|c|c|}
\hline & Root1 & Root2 & Root3 \\
\hline VL & $-1,98819$ & $-1,57184$ & $-2,40517$ \\
\hline L & $-0,97600$ & $-0,82585$ & 0,29550 \\
\hline M & $-0,53359$ & 0,68410 & $-0,04810$ \\
\hline H & 3,62808 & $-0,13936$ & $-0,12894$ \\
\hline VH & 6,35823 & $-0,43751$ & 0,000201 \\
\hline
\end{tabular}




\begin{tabular}{|c|c|c|c|c|c|c|c|c|c|c|c|c|c|c|c|c|c|c|c|c|c|c|c|c|}
\hline $\begin{array}{l}\text { a. } \\
\vdots \\
\overline{0} \\
\dot{b}\end{array}$ & $\stackrel{\mathbb{P}}{>}$ & & $\begin{array}{l}\infty \\
\infty \\
0 \\
\infty \\
0 \\
0\end{array}$ & $\mid \begin{array}{c}n \\
0 \\
\infty \\
0 \\
0 \\
n\end{array}$ & 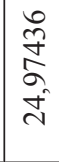 & $\begin{array}{l}\hat{\imath} \\
\hat{n} \\
\hat{0} \\
\hat{i}\end{array}$ & $\begin{array}{l}\mathcal{F} \\
\infty \\
\infty \\
\infty \\
\infty \\
\infty\end{array}$ & $\begin{array}{l}\bar{\sigma} \\
\hat{\sigma} \\
\hat{\alpha} \\
\sigma\end{array}$ & $\begin{array}{l}\infty \\
2 \\
\alpha \\
\alpha \\
\sigma \\
\sigma\end{array}$ & 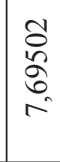 & 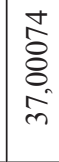 & $\begin{array}{l}\hat{\hat{N}} \\
\hat{\sigma} \\
0 \\
0\end{array}$ & $\begin{array}{l}\infty \\
0 \\
0 \\
0 \\
n \\
n \\
n \\
n\end{array}$ & $\begin{array}{l}0 \\
0 \\
0 \\
i n \\
n \\
\tilde{n}\end{array}$ & $\begin{array}{l}\mathcal{J} \\
\mathfrak{J} \\
f \\
w \\
m\end{array}$ & $\begin{array}{l}\hat{N} \\
\hat{n} \\
n \\
n \\
n\end{array}$ & $\begin{array}{l}\text { D } \\
0 \\
\tilde{B} \\
0 \\
0\end{array}$ & 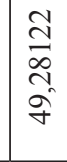 & $\begin{array}{l}\infty \\
0 \\
\infty \\
0 \\
0 \\
\infty \\
\infty \\
n\end{array}$ & $\frac{\hat{n}}{\stackrel{n}{\hat{b}}}$ & 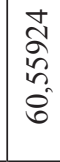 & $\frac{n}{\sigma}$ & $\begin{array}{l}\text { तै } \\
\widehat{ૂ} \\
\hat{b}\end{array}$ & \\
\hline 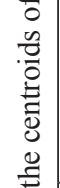 & 工 & & $\begin{array}{l}n \\
\hat{\sigma} \\
\alpha \\
\text { d. }\end{array}$ & 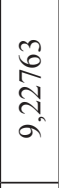 & $\begin{array}{l}0 \\
\mathbb{N} \\
\infty \\
\infty \\
\infty\end{array}$ & $\begin{array}{l}\vec{\sigma} \\
\tilde{\sigma} \\
\infty \\
= \\
=\end{array}$ & $\begin{array}{l}\hat{\tilde{o}} \\
\hat{0} \\
\hat{i}\end{array}$ & $\begin{array}{l}\vec{f} \\
\stackrel{\sigma}{f} \\
\infty \\
\infty\end{array}$ & 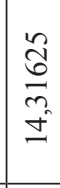 & 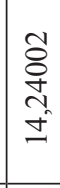 & $\mid \begin{array}{l}\infty \\
0 \\
+1 \\
0 \\
0 \\
0 \\
c\end{array}$ & $\begin{array}{l}2 \\
\alpha \\
0 \\
0 \\
0 \\
0\end{array}$ & \begin{tabular}{|l|}
0 \\
0 \\
0 \\
0 \\
0 \\
0 \\
0
\end{tabular} & $\begin{array}{l}8 \\
\$ \\
\infty \\
\infty \\
\infty\end{array}$ & $\begin{array}{l}0 \\
\infty \\
0 \\
0 \\
\Omega\end{array}$ & 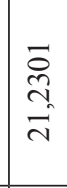 & $\begin{array}{l}n \\
\tilde{\beta} \\
\infty \\
\alpha \\
+ \\
\tilde{c}\end{array}$ & 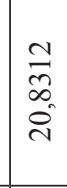 & $\begin{array}{l}\vec{n} \\
\infty \\
n \\
\hat{n} \\
\hat{n}\end{array}$ & $\begin{array}{l}\overrightarrow{\hat{\sigma}} \\
\hat{\sigma} \\
\hat{\sigma} \\
\tilde{c}\end{array}$ & 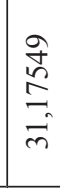 & $\begin{array}{l}\infty \\
2 \\
\hat{2} \\
\hat{2} \\
\hat{n}\end{array}$ & $\begin{array}{l}\overrightarrow{\widehat{\sigma}} \\
\vec{\sigma} \\
0 \\
\dot{m}\end{array}$ & \\
\hline 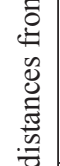 & $\Sigma$ & & $\begin{array}{l}\overrightarrow{\tilde{n}} \\
\vec{f}\end{array}$ & $\begin{array}{l}\infty \\
\stackrel{\infty}{c} \\
\infty\end{array}$ & 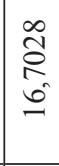 & \begin{tabular}{l}
$\infty$ \\
\multirow{0}{0}{} \\
$\dot{v}$ \\
$\dot{v}$
\end{tabular} & $\begin{array}{l}\bar{b} \\
2 \\
i n\end{array}$ & $\begin{array}{l}\hat{\delta} \\
\hat{o} \\
\hat{o} \\
\hat{t}\end{array}$ & $\begin{array}{l}n \\
\hat{n} \\
\hat{n} \\
\text { n. }\end{array}$ & $\begin{array}{l}\tilde{\delta} \\
\text { î } \\
\text { in }\end{array}$ & $\underset{\text { in }}{=}$ & $\mid \begin{array}{l}n \\
\tilde{n} \\
\vec{\gamma}\end{array}$ & $\mid \begin{array}{c}\tilde{z} \\
\tilde{n} \\
\tilde{y} \\
\tilde{y}\end{array}$ & $\begin{array}{l}\hat{p} \\
\stackrel{f}{\infty} \\
\text { m. }\end{array}$ & $\begin{array}{l}0 \\
\stackrel{n}{0} \\
\text { m. } \\
\text { הi }\end{array}$ & $\begin{array}{l}\tilde{8} \\
\stackrel{\sigma}{q} \\
\dot{q}\end{array}$ & $\begin{array}{l}\text { fo } \\
\text { i } \\
\text { in }\end{array}$ & 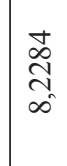 & 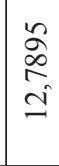 & $\begin{array}{l}n \\
0 \\
0 \\
\mathfrak{n} \\
\mathfrak{y}\end{array}$ & $\begin{array}{l}\hat{a} \\
\stackrel{\hat{Z}}{\Xi}\end{array}$ & $\mid \begin{array}{l}\infty \\
\infty \\
0 \\
0 \\
0 \\
0\end{array}$ & $\begin{array}{l}\text { ठิ } \\
\text { o. } \\
\text { o. }\end{array}$ & \\
\hline 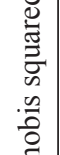 & 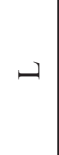 & & $\begin{array}{l}\tilde{n} \\
\dot{f} \\
m\end{array}$ & $\begin{array}{l}\sqrt{2} \\
\tilde{0} \\
\sigma \\
\sigma\end{array}$ & $\begin{array}{l}3 \\
\hat{n} \\
\hat{n} \\
\text { ה }\end{array}$ & 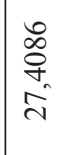 & $\begin{array}{l}\mathscr{0} \\
\text { ff }\end{array}$ & $\begin{array}{l}\tilde{N} \\
\delta \\
\tilde{n} \\
\text { n. }\end{array}$ & 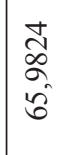 & 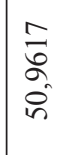 & $\begin{array}{l}\tilde{y} \\
\tilde{y} \\
\tilde{z} \\
\tilde{\delta} \\
n\end{array}$ & $\begin{array}{l}\text { ळे } \\
\text { f }\end{array}$ & $\mid \begin{array}{l}\tilde{\sigma} \\
\infty \\
\approx \\
\vec{n} \\
\ddot{n}\end{array}$ & $\mid \begin{array}{l}\infty \\
2 \\
\hat{\sigma} \\
\hat{\sigma} \\
\dot{q}\end{array}$ & 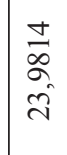 & $\begin{array}{l}\tilde{n} \\
\tilde{\sigma} \\
\tilde{n}\end{array}$ & 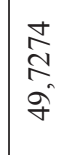 & $\begin{array}{l}0 \\
0 \\
0 \\
0 \\
0 \\
\text { in }\end{array}$ & $\mid \begin{array}{l}\infty \\
\text { i } \\
\text { \$ } \\
\infty \\
\infty\end{array}$ & $\begin{array}{l}\text { ô } \\
\delta \\
\infty \\
\infty\end{array}$ & $\mid \begin{array}{l}\infty \\
\vdots \\
\vdots \\
0 \\
0\end{array}$ & $\begin{array}{l}m \\
\hat{n} \\
n\end{array}$ & 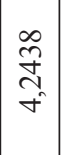 & \\
\hline$\sum_{\Sigma}^{\frac{\sigma}{0}}$ & 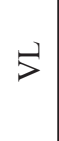 & & $\begin{array}{l}m \\
\stackrel{m}{ \pm} \\
m \\
\stackrel{ \pm}{*}\end{array}$ & 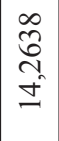 & $\begin{array}{l}\tilde{I} \\
\tilde{y} \\
\tilde{y}\end{array}$ & $\begin{array}{l}2 \\
\hat{\sigma} \\
\hat{q}\end{array}$ & $\begin{array}{l}\grave{\hat{N}} \\
\hat{0} \\
\infty \\
\stackrel{\infty}{i}\end{array}$ & $\begin{array}{l}\bar{o} \\
0 \\
0 \\
i\end{array}$ & 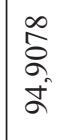 & 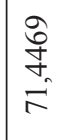 & $\begin{array}{l}\hat{n} \\
\hat{\alpha} \\
\hat{n}\end{array}$ & $\begin{array}{l}\text { సे } \\
\hat{z} \\
\text { bे }\end{array}$ & $\begin{array}{l}\mathbb{J} \\
\text { t } \\
\text { if } \\
\infty\end{array}$ & $\underset{\stackrel{i}{*}}{i}$ & \begin{tabular}{l}
$\stackrel{0}{0}$ \\
$\stackrel{2}{y}$ \\
\multirow{r}{*}{}
\end{tabular} & $\begin{array}{l}\hat{\delta} \\
\tilde{m} \\
\hat{2} \\
\end{array}$ & $\begin{array}{l}\hat{I} \\
\underset{8}{0}\end{array}$ & $\begin{array}{l}0 \\
\sim \\
m \\
\tilde{n}\end{array}$ & $\begin{array}{l}t \\
0 \\
\sigma \\
\sigma \\
\sigma\end{array}$ & $\begin{array}{l}n \\
2 \\
2 \\
n \\
n\end{array}$ & 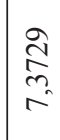 & $\begin{array}{l}\hat{a} \\
\hat{\alpha} \\
\hat{\jmath}\end{array}$ & 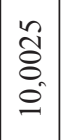 & \\
\hline $\begin{array}{l}\overline{\bar{\theta}} \\
\sum_{0}^{\circ}\end{array}$ & 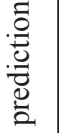 & & \lrcorner & \lrcorner & \pm & $\Psi$ & $\stackrel{\mathbb{I}}{\lessgtr}$ & $\Psi$ & $\stackrel{T}{5}$ & $\stackrel{\mathbb{I}}{\lessgtr}$ & I & $\Psi$ & $\Psi$ & $\Psi$ & $\Sigma$ & $\stackrel{ \pm}{7}$ & \pm & ــ & 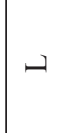 & - & - & - & 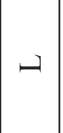 & \\
\hline $\begin{array}{l}\text { चू } \\
\stackrel{0}{0} \\
0 \\
0 \\
0\end{array}$ & 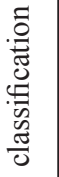 & & 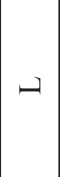 & 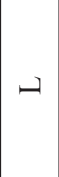 & 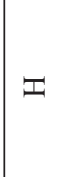 & $I$ & $\Psi$ & $\stackrel{I}{5}$ & $\stackrel{I}{>}$ & $\stackrel{F}{>}$ & $\vec{F}$ & $\vec{F}$ & $\Psi$ & $\Psi$ & $\Sigma$ & $\stackrel{F}{>}$ & \pm & $\Sigma$ & 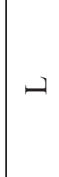 & $\Sigma$ & - & •ـ & 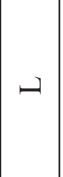 & \\
\hline & $\stackrel{ \pm}{>}$ & & 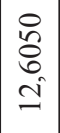 & $\mid \begin{array}{l}3 \\
0 \\
0 \\
\dot{j} \\
m\end{array}$ & $\begin{array}{l}\hat{a} \\
0 \\
\hat{\sigma} \\
\end{array}$ & $\mid \begin{array}{l}\tilde{N} \\
6 \\
0 \\
0 \\
0\end{array}$ & $\begin{array}{l}\bar{m} \\
\tilde{y} \\
\delta \\
0\end{array}$ & \begin{tabular}{l}
$\tilde{N}$ \\
\multirow{\sigma}{\tilde{S}}{} \\
$\tilde{\delta}$
\end{tabular} & 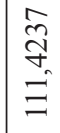 & $\begin{array}{l}\tilde{\delta} \\
\delta \\
i \\
i\end{array}$ & $\begin{array}{l}\frac{\pi}{\sigma} \\
\text { aे }\end{array}$ & 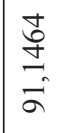 & 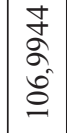 & $\mid \begin{array}{c}\tilde{\sigma} \\
\infty \\
\infty \\
\infty \\
\infty \\
\infty\end{array}$ & $\begin{array}{l}\mathcal{y} \\
\tilde{z} \\
\text { s. } \\
\text { ñ. }\end{array}$ & 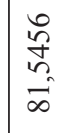 & $\begin{array}{l}\infty \\
\stackrel{\infty}{\hat{~}} \\
\tilde{\gamma}\end{array}$ & $\begin{array}{l}\vec{n} \\
\hat{n} \\
n\end{array}$ & 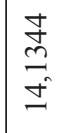 & 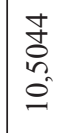 & 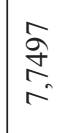 & $\begin{array}{l}\text { సे } \\
\infty \\
\infty \\
\infty \\
\infty\end{array}$ & $\mid \begin{array}{c}\tilde{J} \\
\tilde{z} \\
\hat{\sigma}\end{array}$ & \\
\hline 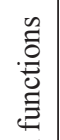 & $\Psi$ & & $\begin{array}{l}0 \\
0 \\
0 \\
n \\
m\end{array}$ & $\begin{array}{l}\overrightarrow{0} \\
\stackrel{m}{2} \\
\stackrel{f}{*}\end{array}$ & $\begin{array}{l}\hat{\mathrm{N}} \\
\stackrel{\mathrm{n}}{2}\end{array}$ & $\mid \begin{array}{l}\bar{y} \\
\tilde{y} \\
\infty \\
\infty\end{array}$ & $\begin{array}{l}\stackrel{2}{ } \\
\text { ఏ } \\
\text { ¿े }\end{array}$ & $\begin{array}{l}\tilde{\sigma} \\
\tilde{\delta} \\
\tilde{\omega} \\
\tilde{\varrho} \\
\varrho\end{array}$ & 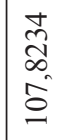 & $\begin{array}{l}\text { ja } \\
\text { के } \\
\text { के }\end{array}$ & 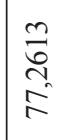 & 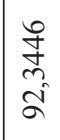 & 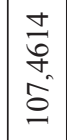 & 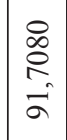 & $\begin{array}{l}2 \\
\hat{2} \\
\hat{6}\end{array}$ & $\begin{array}{l}\underset{J}{J} \\
\tilde{\sigma} \\
\stackrel{2}{2}\end{array}$ & $\mid \begin{array}{l}\tilde{\sigma} \\
\tilde{n} \\
\tilde{f}\end{array}$ & $\begin{array}{l}\tilde{\hat{~}} \\
\tilde{\delta} \\
\tilde{z}\end{array}$ & $\begin{array}{l}\bar{\sigma} \\
\vec{\partial}\end{array}$ & $\begin{array}{l}\bar{\sigma} \\
\alpha \\
\hat{\delta} \\
\sigma\end{array}$ & $\begin{array}{l}\tilde{\sigma} \\
\hat{n} \\
\tilde{n} \\
\tilde{2}\end{array}$ & $\begin{array}{l}0 \\
0 \\
0 \\
\text { o. } \\
\end{array}$ & 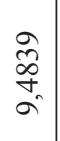 & \\
\hline 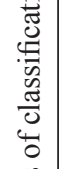 & $\Sigma$ & & $\begin{array}{l}8 \\
0 \\
o \\
\dot{f}\end{array}$ & $\begin{array}{l}0 \\
\infty \\
\stackrel{q}{q} \\
\stackrel{q}{q}\end{array}$ & 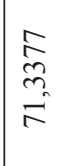 & $\begin{array}{l}2 \\
n \\
n \\
n \\
n \\
n\end{array}$ & 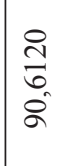 & $\begin{array}{l}\infty \\
\tilde{N} \\
\tilde{\Omega} \\
\tilde{g}\end{array}$ & $\underset{\hat{\sigma}}{\stackrel{\tilde{\sigma}}{\infty}}$ & $\begin{array}{l}\hat{n} \\
\hat{\alpha} \\
\hat{\tilde{n}}\end{array}$ & $\begin{array}{l}\text { సે } \\
\hat{\tilde{b}} \\
\text { }\end{array}$ & $\begin{array}{l}n \\
\tilde{n} \\
n \\
\infty \\
\infty\end{array}$ & 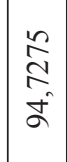 & $\begin{array}{l}\forall \\
\infty \\
\infty \\
\infty \\
\infty\end{array}$ & $\begin{array}{l}\frac{1}{2} \\
\tilde{n} \\
\hat{z} \\
\end{array}$ & $\begin{array}{l}\infty \\
\stackrel{\infty}{n} \\
\vec{\sigma} \\
\tilde{b}\end{array}$ & $\begin{array}{l}\dot{v} \\
\vec{n} \\
\dot{j} \\
\dot{j}\end{array}$ & 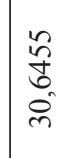 & $\begin{array}{l}n \\
\hat{2} \\
\hat{2} \\
\text { mे }\end{array}$ & $\begin{array}{l}n \\
\hat{\delta} \\
\delta \\
\infty \\
\infty\end{array}$ & $\begin{array}{l}\frac{\partial}{\hat{n}} \\
\dot{\tilde{m}}\end{array}$ & $\begin{array}{l}\infty \\
2 \\
o \\
o \\
\hat{\imath}\end{array}$ & $\begin{array}{l}\frac{\mathcal{J}}{n} \\
\frac{\vec{v}}{v}\end{array}$ & \\
\hline 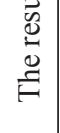 & • & & $\begin{array}{l}\stackrel{\sim}{f} \\
\infty \\
\dot{f}\end{array}$ & $\begin{array}{l}3 \\
\stackrel{0}{+} \\
+\infty \\
\infty \\
+\end{array}$ & $\begin{array}{l}\hat{\hat{\delta}} \\
\hat{0} \\
\infty\end{array}$ & 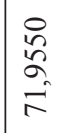 & $\begin{array}{l}0 \\
8 \\
0 \\
\delta \\
\infty\end{array}$ & $\begin{array}{l}\tilde{尺} \\
\tilde{\delta} \\
\infty \\
\infty\end{array}$ & $\begin{array}{l}\tilde{\delta} \\
\delta \\
\delta \\
\infty \\
\infty\end{array}$ & 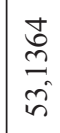 & $\begin{array}{l}\text { के } \\
\text { o } \\
+ \\
\text { fे }\end{array}$ & $\mid \begin{array}{l}\bar{n} \\
\hat{n} \\
\hat{2} \\
\hat{n}\end{array}$ & $\begin{array}{l}\bar{F} \\
\dot{z} \\
\dot{Q}\end{array}$ & \begin{tabular}{|l|}
$\infty$ \\
$\infty$ \\
$\infty$ \\
$\infty$ \\
$\infty$ \\
$\infty$
\end{tabular} & \begin{tabular}{l}
$n$ \\
$\Xi$ \\
\multirow{J}{\Xi}{}
\end{tabular} & 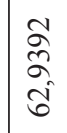 & $\begin{array}{l}\infty \\
\infty \\
\infty \\
\infty \\
\infty \\
\infty\end{array}$ & $\begin{array}{l}\stackrel{\wp}{n} \\
\mathfrak{\sigma} \\
\dot{m}\end{array}$ & $\begin{array}{l}0 \\
\stackrel{\infty}{ \pm} \\
\vec{f} \\
\vec{f}\end{array}$ & $\begin{array}{l}n \\
2 \\
m \\
o \\
q\end{array}$ & 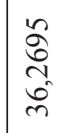 & $\begin{array}{l} \pm \\
\sigma \\
\tilde{a} \\
\text { d }\end{array}$ & $\begin{array}{l}\vec{尺} \\
\stackrel{ }{\sigma}\end{array}$ & \\
\hline & 5 & & $\begin{array}{l}0 \\
\alpha \\
\sigma \\
\delta \\
\tilde{n}\end{array}$ & 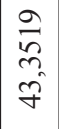 & $\begin{array}{l}n \\
= \\
n \\
n\end{array}$ & 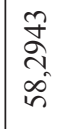 & $\begin{array}{l}n \\
0 \\
\infty \\
0 \\
0 \\
0\end{array}$ & $\begin{array}{l}n \\
8 \\
0 \\
2 \\
i\end{array}$ & $\begin{array}{l}0 \\
8 \\
8 \\
8\end{array}$ & $\begin{array}{l}\stackrel{\hat{t}}{\tilde{N}} \\
? \\
0\end{array}$ & 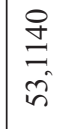 & $\begin{array}{c}\tilde{\sigma} \\
\tilde{o} \\
\tilde{\sigma} \\
\tilde{b}\end{array}$ & $\mid \begin{array}{l}n \\
0 \\
8 \\
\tilde{n}\end{array}$ & $\mid \begin{array}{l}m \\
\tilde{m} \\
\vec{f}\end{array}$ & 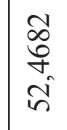 & 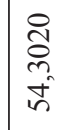 & 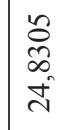 & $\begin{array}{l}\infty \\
0 \\
0 \\
\text { in }\end{array}$ & $\begin{array}{c}\hat{n} \\
\tilde{\delta} \\
\infty \\
\infty\end{array}$ & $\mid \begin{array}{l}\vec{\nabla} \\
\text { D } \\
\infty \\
\infty\end{array}$ & $\begin{array}{l}\hat{\curvearrowright} \\
\tilde{\alpha} \\
\tilde{m}\end{array}$ & 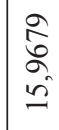 & $\begin{array}{l}\hat{n} \\
\text { के } \\
\infty\end{array}$ & \\
\hline 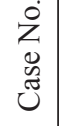 & & $\vdots$ & $\stackrel{m}{m}$ & l & $\bar{n}$ & $\underset{ల}{\infty}$ & ले & f & $F$ & F & F & F & 'f & f & F & $\stackrel{\infty}{+}$ & $\stackrel{g}{q}$ & in & $\vec{n}$ & $\approx$ & $\hat{n}$ & in & in & \\
\hline
\end{tabular}


Table 8. The matrix of classification. Lines: observed classification. Columns: predicted classification.

\begin{tabular}{|c|c|c|c|c|c|c|}
\hline Class & Percentage - Correct & $\mathrm{L}-\mathrm{p}=, 32773$ & $\mathrm{M}-\mathrm{p}=, 50000$ & $\mathrm{H}-\mathrm{p}=, 10924$ & $\mathrm{VH}-\mathrm{p}=, 03782$ & $\mathrm{VL}-\mathrm{p}=, 02521$ \\
\hline $\mathrm{L}$ & 64,19753 & 52 & 27 & 0 & 0 & 2 \\
\hline $\mathrm{M}$ & 88,88888 & 10 & 104 & 2 & 0 & 1 \\
\hline $\mathrm{H}$ & 61,90476 & 0 & 6 & 13 & 2 & 0 \\
\hline VH & 76,92307 & 0 & 0 & 3 & 10 & 0 \\
\hline VL & 83,33334 & 1 & 0 & 0 & 0 & 5 \\
\hline Total & 77,31092 & 63 & 137 & 18 & 12 & 8 \\
\hline
\end{tabular}

at al. [16], who describes the negative relationship between landscape value and the negative elements of anthropogenic origin. The research conducted by Ozimek at al. [37] confirms the fact that margins and lines have an important role in landscape perception; in the model developed in this research they are described by the parameters VCC and HCC. Also, in research conducted by Junge at al. [10], variety had a big influence on landscape preferences, albeit in an experiment that compared rural areas to areas of meadows and forest cover. Similarly, in research carried out in Switzerland by Junge at al. [8], printing fields of partly "leathery" look was not perceived as sloppy, but were clearly liked due to their natural look and variety. The fact that the parameters describing structure complexity and at the same time the landscape view, entail attributes that have the greatest impact on aesthetic quality that was also presented in research results obtained by De la Fuente de Val et al. [18] and Orzechowska-Szajda [38].

Landscape classification for individual classes was completed on the basis of results obtained in pilot research carried out on a $4 \mathrm{~km}$ segment of the Odra River in Wroclaw, with varied landscape. In this research, 20 respondents classified pictures for individual classes of landscape quality. On this basis, a description of classes was performed. Partial results of this pilot research were presented in [38, 39].

Many scientists use various picture media as a source for obtaining data for landscape evaluation. Dramstad et al. [19], Frank et al. [35], Howley [7], Junge et al. [10], Kalivoda et al. [25], Maehr et al [22], Pflüger et al. [40], Tveit [36], and Van Zanten et al. [15] use photographs for social preferences research, whereas Lim et al.
[41] in the research on impact evaluation of planned activities on landscape used 3D visualisations by means of computer-generated graphics. Daniel and Meitner [1] doubt the realism of applied graphical presentations. Hetherington, Daniel and Brown [42], similarly as in this study, used video images to record landscape and presented this as a way of obtaining and presenting data as the most sensitive. Using images recorded by video camera provides many more possibilities for verification of data and to determine the frequency necessity for observation points.

Other research, conducted on the basis of perception, prove that one of the most important elements that have an influence of aesthetic landscape value is flora. Species diversity is an important element that influences landscape aesthetics as confirmed in research carried out in rular/farming landscapes [43-44]. Species complexity, views rich in species increased preferences of farm-tourism landscapes in Norway, the Netherlands, and Switzerland [9, 14]. Zhao at al. [5] obtained other results where species, variety of trees and the presence of water plants constituted negative predictive factors for aesthetic preferences for urban rivers.

Bulut and Yilmaz [17] and Dramstad et al. [19], and Howley [7] again prove that water is of significant importance. The conducted research in the work also shows the following parameters: historical value and landscape dominants contribute the most to the class discrimination of the landscape value. Jungea at al. [10] stresses that hitherto colours and texture have rarely been investigated in landscape preference research. Jungea at al. [10] and Zhao at al. [5] have proven the significance of these parameters. River width, and at the

Table 9. The predicted matrix of the model. Lines: predicted classification. Columns: predicted classification.

\begin{tabular}{|c|c|c|c|c|c|c|}
\hline Class & Percentage of the correct model prediction & VL & $\mathrm{L}$ & M & $\mathrm{H}$ & $\mathrm{VH}$ \\
\hline VL & 100 & 2 & 0 & 0 & 0 & 0 \\
\hline $\mathrm{L}$ & 62,5 & 0 & 30 & 18 & 0 & 0 \\
\hline M & 78,125 & 0 & 13 & 50 & 1 & 0 \\
\hline $\mathrm{H}$ & 100 & 0 & 0 & 0 & 2 & 0 \\
\hline VH & - & - & - & - & - & - \\
\hline Total & 72,41379 & 2 & 48 & 64 & 2 & - \\
\hline
\end{tabular}


same time distance of the view, are also scientifically confirmed, if only by Kalivoda at al. [25], who took into consideration distance in their research (distant/short views), or Strumse [31] in whose research landscape openness was a significant element. Interesting similarities can also be noticed while comparing the results of Real at al. [24] and the received results in this research.

The model obtained in this research finds the dependence between the examined parameters of landscape and the class of its value. The efficiency of the developed model is estimated on the level of $77 \%$. The issues connected with landscape and its assessment are extremely complex. This fact is also emphasized by Feimer at al. [45], maintaining that the desired level of credibility in the landscape research amounts to 0,70 and more. The analysis of wrongly classified cases by the model shows that most cases of function values for the classes observed and predicted by the model are very close. As a rule, they are adjoining classes. This fact can inform a researcher about the probability of the wrong model prediction or about the fact that the value of certain landscapes is on the border of two classes. Palmer and Zube [33] assumed efficiency discriminant function analysis on the level of $75 \%$. The obtained model was verified on the Wisla River in Krakow, and the results showed that the model works on mediumsized rivers such as the Odra or Wisła [46]. It is not known, however, whether the adopted parameters would work on other large rivers in Europe.

\section{Conclusions}

In the source literature there is no research that would evaluate such diverse landscape as in this study, therefore, despite prolific support in the literature for the general methodical assumptions applied in this method, further model predictions with social preferences should be tested in order to evaluate mutual correlations. Further research should also be directed at verifying the usefulness of this method for landscape evaluation in other geographic areas, for other rivers in Europe and worldwide.

This study is one voice in a wide, interdisciplinary discussion on preparing objective methods for landscape evaluation that has been carried out since the 1970s all over the world.

\section{Conflict of Interest}

The authors declare no conflict of interest.

\section{References}

1. DANIEL T.C., MEITNER M.M. Representational validity of landscape visualizations: the effects of graphical realism on perceived scenic beauty of forest vistas. J Environ. Psychol. 21, 61, 2001.

2. FILOVA L., VOJAR J., SVOBODOVA K., SKLENICKA P. The effect of landscape type and landscape elements on public visual preferences: ways to use knowledge in the context of landscape planning. J. Environ. Plann, Manag. 58 (11), 2037, 2015.

3. MEYER B.CH., GRABAUM R. MULBO: Model framework for multicriteria landscape assessment and optimisation. A support system for spatial land use decisions. Landscape Res. 3:2, 155, 2008.

4. RUELLE CH., HALLEUX J-M., TELLER J. Landscape Quality and Brownfield Regeneration: A Community Investigation Approach Inspired by Landscape Preference Studies. Landscape Res. 38 (1), 75, 2013.

5. ZHAO J., LUO P., WANG R., CAI Y. Correlations between aesthetic preferences of river and landscape characters. J. Environ. Eng. Land. 21 (2), 123, 2013.

6. ZHU X., PFUELLER S., WHITELAW P., WINTER C. Spatial Differentiation of Landscape Values in the Murray River Region of Victoria, Australia. J Environ. Manage. 45, 896, 2010.

7. HOWLEY P. Landscape aesthetics: Assessing the general publics' preferences towards rural landscapes. Ecol. Econ. 72, 161, 2011

8. JUNGE X, JACOT K.A., BOSSHARD A., LINDEMANNMATTHIES P. Swiss people'sattitudes towards field margins for biodiversity conservation. J. Nat. Conserv. 17, $150,2009$.

9. JUNGE X., LINDEMANN-MATTHIES P., HUNZIKER M., SCHÜPBACH B. Aesthetic preferences of non-farmers and farmers for different land-use types and pro-portions of ecological compensation areas in the Swiss lowlands. Biol. Conserv. 144, 1430, 2011.

10. JUNGE X., SCHÜPBACH B., WALTERB T., SCHMIDC B., LINDEMANN-MATTHIESD P. Aesthetic quality of agricultural landscape elements in different seasonal stages in Switzerland. Landscape Urban Plan. 133, 67, 2015.

11. LIU Ch., QI T., MA X., The research on the impact assessment of visual landscape of country parks in Beijing. J Environ. Eng. Landsc. 24, 37, 2016.

12. PALMER J.F. Effect size as a basis for evaluating the acceptability of scenic impacts: Ten wind energy projects from Maine, USA. Landscape Urban Plan. 140, 56, 2015.

13. RODRIGUES M., MONTAÑÉS C., FUEYO N. A method for the assessment of the visual impact caused by the largescale deployment of renewable-energy facilities. Environ. Impact Asses. 30, 240, 2010.

14. STILMA E.S.C., SMIT A.B., GEERLING-EIFF F.A., STRUIK P.C., VOSMAN B., KOREVAAR H. Perception of biodiversity in arable production systems in the Netherlands. NJAS-Wageningen, Journal of Life Sciences 56, 391, 2009.

15. VAN ZANTEN B.T., ZASADA I., KOETSE M.J, UNGARO F., HÄFNER K., VERBURG P.H. A comparative approach to assess the contribution of landscape features to aesthetic and recreational values in agricultural landscapes. Ecosystem Services 17, 87, 2016.

16. ARRIAZA M., CAÑAS-ORTEGA J.F., CAÑASMADUEÑO J.A., RUIZ-AVILES P. Assessing the visual quality of rural landscapes. Landscape Urban Plan. 69, 115,2004

17. BULUT Z., YILMAZ H. Determination of waterscape beauties through visual quality assessment method. Environ. Monit. Assess. 154 (1-4), 495, 2009. 
18. DE LA FUENTE DE VAL G., ATAURI J.A., DE LUCIO J.C. Relationship between landscape visual attributes and spatial pattern indices: a test study in Mediterraneanclimate landscape. Landscape Urban Plan. 77 (4), 393, 2006.

19. DRAMSTAD W., TVEIT S.M., FJELLSTAD W.J., FRY G.L.A. Relationships between visual landscape preferences and map-based indicators of landscape structure. Landscape Urban Plan. 78, 465, 2006.

20. LE LAY Y.-F., COTTET M., PIÉGAY H., RIVIÈREHONEGGER A. Ground imagery and environmental perception: using photo-questionnaires to evaluate river management strategies. In: Carbonneau, P., Piégay, H. (Eds.), Fluvial Remote Sensing for Science and Management. WileyeBlackwell, Chichester, 405, 2012.

21. LE LAY Y.F., HERVÉ PIÉGAY H., RIVIÈREHONEGGER A. Perception of braided river landscapes: Implications for public participation and sustainable management. J. Environ. Manage. 119, 1, 2013.

22. MAEHR A.M., WATTS G.R., HANRATTY J., TALMI D. Emotional response to images of wind turbines: A psychophysiological study of their visual impact on the landscape. Landscape Urban Plan. 142, 71, 2015.

23. ODE A., FRY G., TVEIT M.S., MESSAGER P., MILLER D. Indicators of perceived naturalness as drivers of landscape preference, J. Environ. Manage. 90 (1), 375, 2009.

24. REAL E., ARCE C., SABUCEDO J. Classification of landscapes using quantitative and categorical data, and prediction of their scenic beauty in North-Western Spain. J. Environ. Psychol. 20, 355, 2000.

25. KALIVODA O., VOJAR J., SKRIVANOVÁ Z., ZAHRADNÍK D. Consensus in landscape preference judgments: The effects of landscape visual aesthetic quality and respondents' characteristics. J. Environ. Manage. 137, 36, 2014.

26. CHURCHWARD C., PALMER J.F., NASSAUER J.I., SWANWICK C.A. Evaluation of methodologies for visual impact assessments (NCHRP report 741). DC:National Academy of Sciences. Transportation Research Board, Washington, USA, 2013.

27. CASSATELLA C., PEANO A. Landscape Indicators, Assessing and Monitoring Landscape Quality. Springer, 2011.

28. KEARNEY A.R., BRADLEY G.A. The effects of viewer attributes on preference for forest scenes: contributions of attitudes, knowledge, demographic factors, and stakeholder group membership. Environ. Behav. 43, 147, 2011.

29. TVEIT M.S. Indicators of visual scale as predictors of landscape preference; a comparison between groups. J. Environ.Manage. 90, 2882, 2009.

30. HOWLEY P., HYNES S., O DONOGHUE C. The citizen versus consumer distinction: an exploration of individuals' preferences in contingent valuation studies. Ecological Economics 69, 1524, 2010.

31. STRUMSE E. Environmental attributes and the prediction of visual preferences for agrarian landscapes in Western Norway. J. Environ. Psych. 14 (4), 293, 1994.

32. GÓMEZ-SAL A., BELMONTES J.A., NIC J.M. Assessing landscape values: a proposal for a multidimensional conceptual model. Ecol. Model. 168, 319, 2003.
33. PALMER J.F., ZUBE E.H. Numerical and perceptual landscape classification. In: Studies in Landscape Perception. Zube E.H. (Eds.), Amherst: Institute for Man and Environment, University of Massachusetts,70, USA, 1976.

34. BRYAN B.A., RAYMOND C.M., CROSSMAN N., KING D. Comparing spatially explicit ecological and social values for natural areas to identify effective conservation strategies. Conservation Biology 25, 172, 2010.

35. FRANK S., FÜRST CH., KOSCHKE L., WITT A., MAKESCHIN F. Assessment of landscape aestheticsValidation of a landscape metrics-based assessment by visual estimation of the scenic beauty. Ecol. Indic. 32, 222, 2013.

36. TVEIT M., ODE A., FRY G. Key concepts in a framework for analysing visual landscape character. Landscape Res. 31, 229, 2006.

37. OZIMEK A, OZIMEK P., ŁABĘDŹ P. Scenic analyses with application of digital tools. Architektura Krajobrazu Landscape Architecture 3, 4, 2012.

38. ORZECHOWSKA-SZAJDA I. Complexity as an indicator of aesthetic quality of landscape, Technical Transactions Architecture, 10-A/2014, 81, 2014.

39. ORZECHOWSKA-SZAJDA I. The impact of flora on the value of the urban riverside landscape in Wrocław, Architektura Krajobrazu Landscape Architecture, 1/2013, 40, 2013.

40. PFLÜGER Y., RACKHAM A., LARNED S. The aesthetic value of river flows: an assessment of flow preferences for large and small rivers. Landscape Urban Plan. 95 (1-2), 68, 2010

41. LIM E.M., HONJO T., UMEKI K. The validity of VRML images as a stimulus for landscape assessment. Landscape Urban Plan. 77, 80, 2006.

42. HETHERINGTON J., DANIEL T.C., BROWN T.C. Is motion more important than it sounds? The medium of presentation in environmental perception research. J. Environ. Psych. 13, 283, 1994.

43. HASUND K.P., KATARIA M., LAGERKVIST C.J. Valuing public goods of the agricultural landscape: A choice experiment using reference points to capture observable heterogeneity. J. Environ. Plann. Man. 54, 31, 2011.

44. LINDEMANN-MATTHIES P., JUNGE X., MATTHIES $D$. The influence of plant diversity on people's perception and aesthetic appreciation of grassland vegetation. Biol. Conserv. 143, 195, 2010.

45. FEIMER N.R., CRAIK K.H., SMARDON R.C., SHEPPARD S.R.J. Appraising the Reliability of Visual Impact Assessment Methods, In: Proceedings of our national landscape, Elsner G.H., Smardon R.C. (Eds.), A Conference on Applied Techniques for Analysis and Management of the Visual Resource April 23-25 1979, Incline Village, Nevada, 286, 1979.

46. ORZECHOWSKA-SZAJDA I., PODOLSKA A. An assessment of the Cracow landscape from the level of the Vistula River with the use of the urban riverside landscape valuation model, Technical Transactions Environmental Engineering, 1-Ś/2015, 67, 2015. 
